ROCZNIKI HUMANISTYCZNE

$\frac{\text { Tom LXIX, zeszyt } 6-2021}{\text { ZESZYT SPECJALNY }}$

DOI: https://doi.org/10.18290/rh21696s-4

BAS HAMERS

\title{
NEOLOGISMEN IN CORONATIJD - EEN STEEKPROEF
}

\section{INLEIDING}

Op de website van het RIVM (Rijksinstituut voor Volksgezondheid en Milieu) staat het volgende te lezen: "Het coronavirus SARS-CoV-2 veroorzaakt de ziekte COVID-19" (RIVM). Dit specifieke coronavirus werd in de volksmond vanaf de uitbraak in Nederland in maart 2020 al snel hét coronavirus en de ziekte COVID-19 werd al snel simpelweg corona, zoals in "Ik heb corona". Hier zien we een betekenisverschuiving. Een bepaald coronavirus, één van meerdere, wordt namelijk aangeduid met een bepaald lidwoord. Hiermee wordt de suggestie gewekt dat er maar één coronavirus is. Voor het gemak wordt vervolgens ook de ziekte vernoemd naar de verzamelnaam voor de virussensoort, corona. Door deze betekenisverschuiving kunnen we hier spreken van een neologisme.

Crisissituaties, of het nu gaat om een pandemie of andere natuurlijke verschijnselen, financiële crises of oorlogssituaties, brengen bijna altijd neologismen voort, waarvan een deel het schopt tot de Van Dale. Vooral vanwege de mogelijkheid van samengestelde zelfstandige naamwoorden, biedt het Nederlands een vruchtbare grond voor neologismen. Het neologisme anderhalvemetersamenleving bijvoorbeeld, is binnen een mum van tijd opgenomen in Van Dale (toegevoegd april 2020) en is zelfs verkozen tot woord van het jaar 2020: "samenleving die zo is ingericht dat burgers in de publieke ruimte en in publiek toegankelijke locaties ten minste anderhalve

\footnotetext{
Mgr BAS HAMERS - asystent w Katedrze Języka Niderlandzkiego Instytutu Językoznawstwa Katolickiego Uniwersytetu Lubelskiego Jana Pawła II; adres do korespondencji: Katolicki Uniwersytet Lubelski Jana Pawła II, Wydział Nauk Humanistycznych, Al. Racławickie 14, 20-950 Lublin; e-mail: bas.hamers@kul.lublin.pl; ORCID: https://orcid.org/0000-0003-2320-7429.
} 
meter afstand tot anderen kunnen bewaren, m.n. ter voorkoming van virusepidemieën" (Van Dale online).

Voor een uitgebreid onderzoek naar de door COVID-19 geïnspireerde neologismen is het nu nog te vroeg. Ongetwijfeld zal de route naar het nieuwe normaal nog meer neologismen voortbrengen. In deze bijdrage toon ik wel welke coronagerelateerde neologismen we op één willekeurige dag in één landelijk dagblad, De Volkskrant, kunnen aantreffen en hoe daarmee het coronaverhaal tot nu toe verteld kan worden. Ik zal me hierbij alleen richten op samenstellingen van zelfstandige naamwoorden, hierna enkel samenstellingen genoemd.

In hoofdstuk 2 zal de term neologisme gedefinieerd worden en bepaald worden op welke manier de meeste neologismen gevormd worden. De manieren waarop samenstellingen gevormd kunnen worden in het Nederlands, wordt vervolgens in het derde hoofdstuk besproken. In het vierde hoofdstuk zal ik de gevonden coronagerelateerde neologismen categoriseren onder de verschillende soorten samenstelling en dit nader bespreken op basis van verschillende aspecten van de coronacrisis. Hierdoor zal het duidelijk worden in welke mate de coronacrisis het Nederlands al heeft verrijkt. Aangezien het hier om een steekproef gaat, zal dit geen complete lijst van coronagerelateerde neologismen opleveren.

\section{NEOLOGISME}

Een neologisme wordt door Van Dale als volgt gedefinieerd: "nieuwgevormd woord, nieuwe uitdrukking, gebruik van een bestaand woord in een nieuwe betekenis" (Van Dale online). We hebben al het voorbeeld van het coronavirus gezien als betekenisverschuiving. Als we nu spreken over het coronavirus, hebben we het over COVID-19. De definitie van neologisme wordt in Van Dale nog verder toegelicht:

De meeste neologismen in het Nederlands zijn afleidingen en samenstellingen. Afleidingen zijn woorden die met een prefix (bv. antigeluid, verhufteren) of een suffix (bv. contactloos, emotionaliseren) zijn gevormd op basis van een bestaand woord. Samenstellingen zijn het resultaat van de verbintenis van twee (of meer) zelfstandig voorkomende woorden, zoals flitsdaten en kansenzone. Woorden als eetlezen, frisdrank, minkukel en regelneef, die soms als "echte", creatieve nieuwvorming worden gepresenteerd, zijn in werkelijkheid ook meestal afleidingen of samenstellingen: eetlezen van eten + lezen, frisdrank van fris + drank, minkukel van min + kukel (een door schrijver Marten Toonder bedacht fantasiewoord voor intelligentie, iets dat bij wezens met een hoog IQ gemeten wordt) en regelneef uit regelen + neef. (Van Dale online) 
Echt nieuwe woorden waaruit de betekenis niet af te leiden is komen niet zo vaak voor. Zoals we hierboven zien, bestaan de meeste neologismen uit al bestaande woorden en/of prefixen en suffixen. Over nieuwvormingen zegt Nicoline van der Sijs: "Het grootste aantal nieuwvormingen wordt gemaakt door samenstelling of afleiding. Samenstelling is de samenkoppeling van twee woorden tot een nieuw woord, zoals tafelpoot, schoenveter" (Van der Sijs 8)

Aangezien het grootste aantal neologismen wordt gevormd door samenstelling, en omdat samenstellingen zo typerend zijn voor het Nederlands, concentreer ik me in deze bijdrage op coronagerelateerde neologismen in de vorm van samengestelde zelfstandige naamwoorden.

\section{SAMENSTELLINGEN}

In het Nederlands zijn er verschillende manieren waarop zelfstandige naamwoorden samengesteld kunnen worden. De Algemene Nederlandse Spraakkunst (verder ANS) spreekt over een samenstelling als er van twee woorden, waarvan er ten minste één een substantief is, een nieuw substantief gevormd wordt (Haeseryn 681). Door het gebruik van samenstellingen kan er iets kernachtig uitgedrukt worden. Het eerder genoemde anderhalvemetersamenleving is hier een goed voorbeeld van. De zin "We leven in een anderhalvemetersamenleving" is kernachtiger dan "We leven in een samenleving waarin we anderhalve meter afstand moeten houden van elkaar". Het tweede lid van anderhalvemetersamenleving is een substantief, namelijk samenleving. Het tweede lid bij samengestelde substantieven is altijd een substantief. Het eerste lid kan bestaan uit een substantief, een telwoord, een adjectief, een bijwoord, een werkwoordsstam of een groep woorden (682).

Ter verduidelijking volgen hieronder voor elke categorie voorbeelden van neologismen die ontstaan zijn uit eerdere crisissituaties, zoals natuurrampen, financiële crises, oorlogen, e.d.

\subsection{Substantief + substantief}

De discussie over het klimaat en de opwarming van de aarde met bijbehorende gevolgen heeft veel neologismen opgeleverd. Tot de categorie substantief + substantief kunnen we bijvoorbeeld klimaatvluchteling rekenen. Van Dale definieert dit neologisme als: "iem. die zijn woongebied verlaten heeft vanwege barre omstandigheden die worden toegeschreven aan klimaatveranderingen" (Van Dale online). 


\subsection{Telwoord + substantief}

$\mathrm{Nu}$ er steeds minder mensen zijn die de Tweede Wereldoorlog bewust hebben meegemaakt en traumatische ervaringen hebben moeten verwerken, komt er meer aandacht voor de trauma's bij de kinderen van deze mensen, de zogenoemde tweedegeneratieslachtoffers. Dit neologisme werd in oktober 2013 toegevoegd en als volgt gedefinieerd door Van Dale: "iem. die getraumatiseerd is door dramatische gebeurtenissen die een of beide ouders hebben meegemaakt" (Van Dale online).

\subsection{Adjectief + substantief}

Ook samenhangend met de klimaatdiscussie is het in oktober 2014 aan Van Dale toegevoegde fijnstof: "stofdeeltjes met een doorsnede van minder dan 10 micrometer, hetzij van nature in de lucht aanwezig, hetzij daarin terechtgekomen door menselijke activiteiten, m.n. door verbrandingsprocessen (ook: fijn stof)" (Van Dale online). Opvallend is dat het ook nog los van elkaar geschreven kan worden. De afgelopen jaren is het echter een in de klimaatdiscussie zoveel gebruikte term, dat het als één woord wordt beschouwd.

\subsection{Bijwoord + substantief}

Tijdens de coronacrisis zijn er veel beperkingen die tot gevolg hebben dat we meer alleen zijn. Als er weer meer gemeenschappelijke activiteiten mogelijk zijn, krijgen sommige mensen last van alleenschaamte, of zoals het Instituut voor de Nederlandse Taal formuleert: "Schaamte die iemand voelt als hij dingen alleen onderneemt, zoals uit eten of naar de film gaan, met name in coronatijd, omdat hij het idee heeft dat hij in zijn eentje voor meer (vooral logistieke) overlast zorgt" (IVDNT 2021). Dit woord is niet opgenomen in Van Dale.

\subsection{Werkwoordstam + substantief}

De schaamte komt terug in de klimaatkwestie, zoals in het woord vliegschaamte. Vliegschaamte kan men ondervinden als er geen gebruik wordt gemaakt van schonere vervoermiddelen in plaats van het vliegtuig, of zoals Van Dale het definieert: "schaamte die iemand ervaart als hij of zij gebruikmaakt van een vliegtuig terwijl er minder milieubelastende alternatieven zijn om zich te verplaatsen" (Van Dale online). 


\subsection{Groepen van woorden + substantief}

Cybercriminaliteit neemt snel toe met de steeds verdergaande digitalisering van de maatschappij. De coronacrisis en de daarmee nog verder toegenomen digitalisering van het dagelijks leven heeft deze vorm van criminaliteit alleen maar doen toenemen. Het is daarom van groot belang al onze data van begin tot eind te beveiligen. Dit kan door de zogenoemde end-to-endencryptie, een woord dat in april 2018 aan Van Dale is toegevoegd: "vorm van digitale beveiliging waarbij alleen zender en ontvanger een bericht kunnen lezen" (Van Dale online).

\section{METHODIEK}

Om te bepalen hoeveel coronagerelateerde neologismen er gebruikt worden in de media is een veel uitgebreider onderzoek nodig. Taalpublicist en hoofdredacteur bij de Dikke Van Dale, Ton den Boon houdt al sinds maart 2020 - vrijwel vanaf het begin van de crisis - een coronawoordenboek bij op taalbank.nl. ${ }^{1}$ De snelle groei van dit coronagerelateerde woordenboek verklaart Den Boon door een karakteristieke eigenschap van het Nederlands, namelijk de mogelijkheid van het maken van samenstellingen. Volgens Den Boon helpt het ook dat er in Nederland nog veel kranten verschijnen en dat juist door de kranten veel nieuwe woorden worden gemaakt (Onkenhout).

Het kan de moeite waard zijn om steekproefsgewijs te kijken hoeveel coronagerelateerde neologismen er al te vinden zijn in een groot landelijk dagblad, in dit geval De Volkskrant, op een willekeurige dag, namelijk 16 april 2021, en in hoeverre het coronaverhaal - de ontwikkeling van de crisis hiermee verteld kan worden. In de zoekfunctie van de online versie van De Volkskrant heb ik het woord corona ingegeven en vervolgens uit de verkregen artikelen de coronagerelateerde neologismen gezocht, en wel in de vorm van een samenstelling. Het woord corona hoeft hierbij geen deel uit te maken van de samenstelling. De zo verkregen samenstellingen zal ik vervolgens onderverdelen in de reeds besproken zes categorieën. Verder zal ik het neologisme nader bespreken en nagaan of het al in Van Dale online is opgenomen. Er zijn meer woordenboeken en woordenlijsten die voortdurend geactualiseerd worden, zoals Woordenlijst Nederlandse Taal en ook Instituut

\footnotetext{
${ }^{1}$ Zie www.taalbank.n1/2020/03/14/coronawoordenboek. De taalbank.nl is een weblog over taalverandering.
} 
voor de Nederlandse taal houdt zich bezig met neologismen. Voor het dagelijks taalgebruik en voor de alledaagse taalgebruiker, wordt Van Dale echter als standaard naslagwerk gezien.

Aangezien de coronacrisis op 16 april al ruim een jaar ons leven - en dus ook de media - beheerst, verwacht ik niet dat ik veel neologismen zal vinden die te maken hebben met de maatregelen en reacties van het eerste uur, zoals anderhalvemetersamenleving en coronahamsteren. Verder verwacht ik weinig woorden tegen te komen die te maken hebben met de allang vervlogen lof die het zorgpersoneel toegeworpen kreeg aan het begin van de crisis, zoals zorgheld of corona-applaus. Ook de complottheorieën zijn al min of meer uit het publieke debat verdwenen. Woorden als coronacomplot verwacht ik ook niet veel tegen te komen. In januari is in Nederland begonnen met het vaccineren tegen het coronavirus en dit wordt gezien als het begin van het einde. Het vaccinatieproces wordt echter gekenmerkt door de nodige obstakels, van een tekort aan vaccins, onvoorziene bijwerkingen, logistieke problemen, vaccinweigeraars en discussies over de prioritering. Ik verwacht daarom een redelijk aantal hiermee samenhangende neologismen aan te treffen. Het feit dat het vaccineren is begonnen, betekent ook dat we in een overgangsfase zitten naar onze vertrouwde precorona maatschappij. Ik verwacht hiermee samenhangende neologismen ook in een redelijk aantal aan te treffen.

\section{STEEKPROEF}

In de online versie van De Volkskrant van 16 april heb ik 15 artikelen verkregen na het invoeren van de zoekterm corona. In één van die artikelen heb ik geen coronagerelateerde neologismen in de vorm van een samenstelling gevonden. In de overige 14 artikelen ben ik in totaal 25 neologismen tegengekomen. Ik zal deze neologismen onderverdelen in de 6 categorieën van samenstellingen en binnen deze categorisering verder onderverdelen in de coronagerelateerde thematiek, te weten de verschillende fasen van de pandemie: a) ziekte en pandemie; b) maatregelen; c) gevolgen; d) overgang naar normaal/ postcorona; e) vaccinatie. Ik zal enkel die categorieën vermelden waarin ik neologismen heb gevonden. 


\subsection{Substantief + substantief}

\section{ZIEKTE- EN PANDEMIEGERELATEERD}

Het is niet verrassend dat we het woord coronacrisis tegenkomen, op 16 april 2021 zit Nederland er namelijk nog middenin: "U zit misschien nog volop in de coronacrisis, het kabinet is vast begonnen met de evaluatie" (Bessems). Verderop in het artikel komen we covidpatiënten tegen: "Want het door deze ministers zelf zo geprezen beleid is om golf na golf de ziekenhuisbedden vol te laten lopen met covidpatiënten, ten koste van andere zorg" (Bessems). In feite is deze term correcter dan coronapatiënt, aangezien covid de ziekte is. Beide bovengenoemde samenstellingen worden al als voorbeeld van een samenstelling genoemd in Van Dale.

De coronacrisis wordt veroorzaakt door de coronapandemie: "De heropening van ons sociale leven is weer uitgesteld, tot de piek van de derde golf in de coronapandemie voorbij is" (Noorlander). Aan de elk jaar terugkerende griepepidemie zijn we gewend, maar doordat het coronavirus wereldwijd om zich heen greep werd dit een pandemie. Coronapandemie wordt in Van Dale ook al als samenstelling genoemd.

De hevigheid waarmee het virus toeslaat, verschilt per land en per periode. Er is dus sprake van verschillende coronagolven: "In India is het aantal positieve testen nu veel hoger dan in de eerste coronagolf; het dichtbevolkte land meldde de afgelopen maand 2,6 miljoen besmettingen, ruim eenderde van alle meldingen in Azië" (Ajrovic, De Jager). Vanwege de snelle verspreiding van het coronavirus in India, is dit land een coronaland op dit moment: "Totdat een reiziger het virus per ongeluk meeneemt uit een 'coronaland', en het herintroduceert in een bevolkingsgroep die zich niet heeft laten vaccineren" (Keulemans). Tijdens de coronapandemie zijn veel landen al aangemerkt als coronaland, wat zoveel betekent als risicoland. De samenstellingen coronagolf en coronaland worden in Van Dale nog niet genoemd.

\section{CORONAMAATREGELEN}

Het woord coronamaatregelen komen we nog tegen op 16 april 2021. Veel maatregelen zijn namelijk nog van kracht en er wordt ook nog regelmatig tegen geprotesteerd. De coronamaatregelen hebben ook grote invloed op de beleving van sport: "Publiek, uitgerekend bij landenwedstrijden in het tennis een factor van belang, ontbreekt door de coronamaatregelen" (Giebels). In Van Dale vinden we deze samenstelling nog niet terug. 
De coronamaatregelen zijn een manier om de coronabestrijding vorm te geven: "Al is die nu in een andere hoedanigheid nog even druk met het uitdelen van miljarden uit een fonds van dit kabinet, opgericht door de ministers Hoekstra en Wiebes, die herhaaldelijk de coronabestrijding hebben getraineerd" (Bessems). Er zijn verschillende manieren om deze coronabestrijding vorm te geven, zoals het invoeren van een coronalockdown: "Voor miljoenen kwetsbare Nederlanders zijn in het afgelopen jaar al zoveel deuren dichtgegooid, dat we aan één openingsplan voor na de coronalockdown niet genoeg hebben om dat weer te repareren" (Noorlander). Er zijn verschillende soorten lockdowns, van een harde lockdown, tot een minder strenge, zoals een weekendlockdown: "De weekendlockdown in Suriname is nodig vanwege "fragiele gezondheidszorg"” (Ajrovic, De Jager 2021). Coronalockdown en weekendlockdown worden niet vermeld in Van Dale.

Een ander middel om corona te bestrijden is de coronatest, waarvan we er al verschillende kennen, zoals de PCR-test, de antigeentest en de recentere zelftest. Het aantal officiële coronatesten wordt bijgehouden in de statistieken: "Onderstaande grafiek laat zien hoeveel procent van de dagelijkse coronatesten positief was" (Van Uffelen). Coronatest wordt al vermeld in Van Dale als samenstelling.

Het aantal positief geteste personen, besmettingen, de spreiding ervan en het aantal vaccinaties is op de voet te volgen op het coronadashboard van de Rijksoverheid: "Op het corona-dashboard van de overheid zijn de nieuwste leveringsgetallen van Pfizer nog niet verwerkt" (Van der Geest). Deze samenstelling wordt niet vermeld op Van Dale. De ontwikkeling van de pandemie en nieuwe maatregelen worden door de overheid bekend gemaakt tijdens de covidconferenties: "In iedere covid-persconferentie wordt de mogelijkheid buiten of binnen te sporten, en in wat voor groepen dan en vanaf welke leeftijd, uitgebreid besproken" (Sluimer). Vooral in het begin van de coronacrisis brachten deze momenten de Nederlanders massaal samen voor de televisie. We komen ook wel corona-persconferentie tegen. Voor beide samenstellingen valt wat te zeggen. De persconferenties gaan over de verspreiding van het coronavirus, maar ook om het aantal patiënten met covid. Covidpersconferentie wordt echter niet vermeld als samenstelling in Van Dale, terwijl dit wel het geval is bij coronapersconferentie.

Ondanks alle maatregelen genomen door de overheid, is het de vraag in hoeverre de mensen zich daaraan houden. De maatregelen brengen ook de creatieve mens naar boven, waardoor er een verschil is tussen de coronatheorie en de coronapraktijk: "Italië is zeker niet het enige land waar coronatheorie en -praktijk soms ver uit elkaar liggen, maar de onverstoorbaarheid waarmee Italianen om hun regels heen bewegen is bijna bewonderenswaardig" (Van 
Gool). Ook in Nederland zijn er talrijke voorbeelden van pogingen tot het omzeilen van de coronamaatregelen. Coronatheorie en coronapraktijk vinden we niet terug in Van Dale.

\section{GEVOLGEN VAN CORONA}

De impact van de coronapandemie is groot. Gesloten winkels, bedrijven en horeca veroorzaken grote coronaschade voor de Nederlandse economie: "De coronaschade wordt inmiddels uitgedrukt in bedragen die het honderdvoudige hiervan [144 miljoen] bedragen en niemand knippert met zijn ogen" (Klok). Er is echter niet alleen economische schade. Ook in het dagelijks leven krijgen mensen te maken met de gevolgen van de coronacrisis. Deze gevolgen zijn niet alleen van psychische aard, maar ook van fysieke: "WWe zijn miljoenen coronakilo's aangekomen', zei premier Mark Rutte een poosje geleden nog zorgelijk" (Sluimer). Het lijkt erop dat het vele thuiswerken en de daarmee samengangende stress, ook de neiging tot snacken en borrelen heeft doen toenemen. Ook de gesloten sportverenigingen en scholen zullen vermoedelijk hebben bijgedragen aan de coronakilo's. In Van Dale vinden we deze samenstelling overigens nog niet terug.

\section{VACCINATIE}

In januari 2021 is Nederland begonnen met vaccineren tegen covid-19. De bedoeling is dat tegen 1 juli 2021 iedereen de eerste coronavaccinatie heeft gehad: "Jaap van Delden, programmadirecteur coronavaccinatie bij het RIVM, spreekt in de Tweede Kamer van een 'bemoedigende' situatie, ondanks de problemen met de vaccins van AstraZeneca en Janssen" (Frijters en Hofstede). Om dit doel te bereiken, moet er dagelijks een flink aantal coronaprikken gezet worden: "Deze week zijn in Nederland ruim 100 duizend coronaprikken per dag gezet" (ibid.). In Van Dale vinden we coronavaccinatie en coronaprik nog niet terug als samenstelling.

\section{TERUG NAAR NORMAAL}

Met het toenemende aantal gevaccineerden, is ook de hoop op een snelle terugkeer naar normaal toegenomen. Dit is echter een geleidelijk proces. Door de coronamaatregelen werd reizen sterk beperkt, waardoor de reisbranche zwaar getroffen werd en de meeste mensen hun jaarlijkse buitenlandse vakantie misten. Om te testen hoe een georganiseerde reis in het coronatijdperk aangepakt kan worden, mag een beperkt aantal mensen naar een buitenlandse 
bestemming om informatie te verkrijgen over hoe we coronaveilig op vakantie kunnen gaan. De uitverkorenen kunnen beschouwd worden als proefkonijn, oftewel proeftoeristen: "Maandagmiddag vertrokken 189 'proeftoeristen' naar het Griekse eiland Rhodos" ("De Betrouwbare Mannetjes"). Ook dag- of weekenduitstapjes zitten er vooralsnog niet in. Hierbij valt te denken aan concerten of misschien nog belangrijker in Nederland festivalland, de elk jaar terugkerende grote en kleinere festivals. Ook op dit gebied wil de overheid te weten komen wat er op dit moment en in de toekomst mogelijk is met behulp van proefevenementen. De gelukkigen die werden uitverkoren waren enthousiast uiteraard, maar er was de nodige kritiek op de gezondheidsrisico's en de kosten: "Hoorden dat er bij jullie veel kritiek is op de 1,1 miljard euro die het demissionaire kabinet voor de verschillende proefevenementen opzij heeft gezet" ("De Betrouwbare Mannetjes"). Deze samenstellingen zijn nog niet terug te vinden in Van Dale.

\subsection{Werkwoordstam + substantief}

\section{CORONAMAATREGELEN}

Om de afnamecapaciteit van testen te vergroten, werden er teststraten ingericht, straten om op grote schaal en in een hoog tempo te testen: "Nu liggen ze te verstoffen achter in de kast, naast wat ongebruikte sneltests en een foldertje dat $\mathrm{u}$ ooit meekreeg bij de teststraat" (Keulemans). Dit valt terug te leiden op het lopende bandprincipe. Sinds augustus 2020 staat teststraat ook in Van Dale, zij het in een algemenere betekenis: "ruimte waarin bij personen of zaken die zich er doorheen bewegen, achtereenvolgens tests worden gedaan" (Van Dale online). Aan te nemen valt dat dit woord is toegevoegd naar aanleiding van de coronateststraten.

\section{VACCINATIE}

Een vaccinatie wordt in de volksmond ook wel een prik genoemd, het prikken in de arm om vervolgens de vaccinatie toe te kunnen dienen. Deze term zien we dan ook vaak terugkomen in krantenartikelen. De prikcampagne is in Nederland in januari begonnen, en wordt verdeeld in verschillende prikrondes, gebaseerd op beroepsgroep, kwetsbaarheid en leeftijd: "Minister De Jonge had de ziekenhuizen al eerder vaccins toegezegd, voor de zorgmedewerkers die in de eerste prikronde in januari nog niet aan bod waren gekomen" (Huisman). Als de persoon uit betreffende doelgroep aan de beurt 
is, moet er wel eerst een prikafspraak gemaakt worden: "Bij de GGD'en kunnen inmiddels ook de mensen die geboren zijn in 1952 (die dus dit jaar 69 worden) een prikafspraak maken" (Van der Geest). De samenstellingen prikronde en prikafspraak zijn niet terug te vinden in Van Dale.

Tijdens de vaccinatiecampagne worden er vaccins van verschillende farmaceuten gebruikt: "De Pfizer-vaccins verzachten de pijn van het besluit dat nu AstraZeneca (4,3 miljoen vaccins in het tweede kwartaal) alleen kan worden ingezet bij zestig-plussers, en ook de prikcampagne met Janssen stilligt" (Van der Geest). Tijdens de vaccinatiecampagne ontstonden er problemen met de levering van de vaccins en bijwerkingen bij bepaalde vaccins. Dit betekende dat er een tijdelijke prikstop kwam, al hield niet iedereen zich daaraan: "Limburgs ziekenhuis: prikstop of niet, wij gaan jonge zorgmedewerkers inenten met AstraZeneca" (Huisman). Ook prikstop is nog niet opgenomen in Van Dale.

\subsection{Groepen van woorden + substantief}

\section{TERUG NAAR NORMAAL}

Met de vaccinatiecampagne in volle gang en de versoepeling van de coronamaatregelen, wordt er ook weer gedacht aan vakanties. De onzekerheid en de angst voor een nieuwe coronagolf blijft echter. Vandaar dat mensen graag een slag om de arm houden, in dit geval een corona-slag-om-de-arm: "Toch diende het perfecte huisje zich aan, nota bene naast een alpenwei! Zouden we dat met een corona-slag-om-de-arm kunnen huren? We begonnen alvast wandeltochten in de omgeving uit te zoeken" (Cornelisse). Ook coronaslag-om-de-arm vinden we niet terug in Van Dale.

\section{CONCLUSIE}

Crisissituaties en de gevolgen daarvan brengen vaak neologismen voort, vooral als het gaat om een crisissituatie waarmee de huidige wereld voor het eerst wordt geconfronteerd. De mens, en vooral de media, heeft de behoefte om de nieuwe omstandigheden te benoemen. Dit blijkt ook uit de steekproef. In de 14 coronagerelateerde Volkskrant-artikelen werden 25 neologismen gevonden in de vorm van een samenstelling. Verreweg de meeste samenstellingen (19) vallen onder de categorie substantief + substantief. Dit is niet verrassend, omdat bij veel samenstellingen het linkerlid bestaat uit corona-. Vervolgens werden er in de categorie werkwoordstam + substantief 5 neologismen gevonden. Deze 
hadden allemaal als linkerlid test- of prik-. Dit is ook niet verrassend, omdat Nederland middenin de vaccinatiecampagne zit. Bovendien is testen essentieel in de overgangsperiode naar de postcoronasamenleving. In de categorie groep van woorden + substantief werd 1 neologisme gevonden. Deze had te maken met de onzekerheid over de toekomst.

Wat de coronagerelateerde thematiek betreft, komen we in elke categorie neologismen tegen, waarbij het niet verrassend is dat in de categorieën terug naar normaal en vaccinatie redelijk veel neologismen (9) voorkomen. Nederland zit namelijk middenin de vaccinatiecampagne, een campagne die ook wel gezien wordt als de weg terug naar normaal. Ook was te verwachten dat er in de categorieën Ziekte- en pandemiegerelateerd (5) en Coronamaatregelen (9) nu nog steeds veel neologismen zijn terug te vinden in de krant. De pandemie is immers nog in volle gang en dat betekent dat er nog steeds maatregelen van kracht zijn. In de landen waar de situatie verbetert, wordt juist veel gepraat over versoepeling van die maatregelen. In de categorie Gevolgen van corona werden er tenslotte 2 neologismen aangetroffen.

De meeste gevonden neologismen worden nog niet vermeld in Van Dale online. Vooral voor de neologismen in de categorieën terug naar normaal en vaccinatie is het daar ook nog te vroeg voor. De tijd zal het leren welke het zullen halen. Dit zal ook samen hangen met de duur van de coronacrisis en dus de frequentie waarmee de woorden in de (sociale) media verschijnen. Dat is namelijk een van de criteria die Van Dale hanteert bij het opnemen van nieuwe woorden: "Een woord wordt opgenomen in de Dikke Van Dale als de redactie dat woord gedurende langere tijd regelmatig aantreft in kranten, tijdschriften, boeken en op internet (inclusief blogs en sociale media). Het woord moet algemeen bekend zijn, het moet ingeburgerd zijn. Verder moet het woord in veel verschillende soorten teksten voorkomen" (Van Dale). Dit proces kan heel snel gaan, zoals in het geval van de neologismen coronacrisis en coronacrisis, die al opgenomen zijn in Van Dale online.

Op het moment van schrijven, zitten we in een overgangsperiode. Het aantal gevaccineerden stijgt en de weg terug naar normaal is ingezet. Toch is er nog veel onzekerheid. Komt er een nieuwe golf? Wat zullen de gevolgen zijn van virusmutaties? Kunnen we groepsimmuniteit bereiken? Deze onzekerheid en nieuwe ontwikkelingen zullen onvermijdelijk tot nieuwe neologismen leiden. Dit kan weer voer zijn voor vervolgonderzoek. Hierbij zou ook een vergelijking gemaakt kunnen worden met coronagerelateerde neologismen in Vlaamse media. Niet voor niets zien we al een opvallend verschil in het Van Dale-woord van het jaar 2020 in Nederland - anderhalvemetersamenleving en in Vlaanderen - knuffelcontact. 


\section{GECITEERDE WERKEN}

"Alleenschaamte". Instituut voor de Nederlandse Taal, 16 apr. 2021, www.ivdnt.org/actueel/ woorden-van-de-week/nieuw-woord-van-de-week/alleenschaamte . Opgevraagd 17 apr. 2021.

Ajrovic, Semina, en De Jager, Nick. "Weekendlockdown in Suriname, Denemarken versoepelt eerder dan gepland". De Volkskrant, 16 apr. 2021, www.volkskrant.n1/nieuws-achtergrond/ weekendlockdown-in-suriname-denemarken-versoepelt-eerder-dan-gepland b20a560a. Opgevraagd 16 apr. 2021.

Bessems, Kustaw. "Corona? Het kabinet is al aan de evaluatie toe en geeft zichzelf een pluim". De Volkskrant, 16 apr. 2021, www.volkskrant.nl/columns-opinie/corona-het-kabinet-is-al-aan-deevaluatie-toe-en-geeft-zichzelf-een-pluim b5bb647d. Opgevraagd 17 apr. 2021.

Cornelisse, Paulien. "Je zou op elke vakantiehuisjessite moeten kunnen aanvinken: geen lederen bankstel”. De Volkskrant, 16 apr. 2021, www.volkskrant.nl/mensen/je-zou-op-elke-vakantiehuisjessitemoeten-kunnen-aanvinken-geen-lederen-bankstel b485348f. Opgevraagd 17 apr. 2021.

"De Betrouwbare Mannetjes zijn er even helemaal uit". De Volkskrant, 16 apr. 2021, www.volkskrant.nl/ columns-opinie/de-betrouwbare-mannetjes-zijn-er-even-helemaal-uit $\sim$ b06e316f. Opgevraagd 17 apr. 2021.

Frijters, Serena, en Sjors Hofstede. "Sterfte weer iets hoger dan verwacht, 100 duizend vaccinaties per dag". De Volkskrant, 16 apr. 2021, www.volkskrant.nl/nieuws-achtergrond/sterfte-weer-ietshoger-dan-verwacht-100-duizend-vaccinaties-per-dag bdf93c4d. Opgevraagd 17 apr. 2021.

Giebels, Robert. "Zege voor Nederland is balsem op de geplaagde ziel van tennisster Kiki Bertens". De Volkskrant, 16 apr. 2021, www.volkskrant.nl/sport/zege-voor-nederland-is-balsem-op-degeplaagde-ziel-van-tennisster-kiki-bertens $\sim$ b99a4129. Opgevraagd 17 apr. 2021.

Haeseryn, W. et al. Algemene Nederlandse Spraakkunst. 2de ed., Martinus Nijhoff Uitgevers, 1997.

Huisman, Charlotte. "Limburgs ziekenhuis: prikstop of niet, wij gaan jonge zorgmedewerkers inenten met AstraZeneca". De Volkskrant, 16 apr. 2021, www.volkskrant.nl/nieuws-achtergrond/limburgsziekenhuis-prikstop-of-niet-wij-gaan-jonge-zorgmedewerkers-inenten-met-astrazeneca be $0 \mathrm{c} 8 \mathrm{f} 38$. Opgevraagd 17 apr. 2021.

Keulemans, Maarten. "Wat voor ziekte wordt corona als de crisis straks echt voorbij is?" De Volkskrant, 16 apr. 2021, www.volkskrant.nl/wetenschap/wat-voor-ziekte-wordt-corona-als-decrisis-straks-echt-voorbij-is b419a825. Opgevraagd 17 apr. 2021.

Klok, Pieter. "Wordt die miljardenschuld straks een probleem?" De Volkskrant, 16 apr. 2021, www.volkskrant.nl/columns-opinie/wordt-die-miljardenschuld-straks-een-probleem b8070e04. Opgevraagd 17 apr. 2021.

Noorlander, Leon. "Bij het leven na de lockdown moeten we extra aandacht geven aan de kwetsbaren, die het meest zijn getroffen door de epidemie". De Volkskrant, 16 apr. 2021, www.volkskrant.nl/ columns-opinie/bij-het-leven-na-de-lockdown-moeten-we-extra-aandacht-geven-aan-de-kwetsbarendie-het-meest-zijn-getroffen-door-de-epidemie b1bd3082. Opgevraagd 17 apr. 2021.

Onkenhout, Paul. "De coronacrisis prikkelt het Nederlandse taalgevoel: al 700 nieuwe woorden". De Volkskrant, 28 apr. 2020, www.volkskrant.nl/cultuur-media/de-coronacrisis-prikkelt-het-nederlandsetaalgevoel-al-700-nieuwe-woorden $\sim$ b79d48ab. Opgevraagd 3 juli 2021.

Peters, Guus. "Judoka Verhagen verliest op EK en de Nederlandse ploeg verliest met haar". De Volkskrant, 16 apr. 2021, www.volkskrant.nl/sport/judoka-verhagen-verliest-op-ek-en-de-nederlandseploeg-verliest-met-haar bde3201d. Geraadpleegd op 17 april 2021. 
Rijksinstituut voor Volksgezondheid en Milieu, www.rivm.nl/coronavirus-covid-19. Opgevraagd 16 apr. 2021.

Sijs, Nicoline van der. Leenwoordenboek. De invloed van andere talen op het Nederlands. 3de ed., Sdu Uitgevers, 1997.

Sluimer, Sarah. "Gezondheid mag nooit een verplichting worden”. De Volkskrant, 16 apr. 2021, www.volkskrant.nl/columns-opinie/gezondheid-mag-nooit-een-verplichting-worden $\sim$ bfadf303. Opgevraagd 17 apr. 2021.

Van Dale Groot woordenboek der Nederlandse taal online, zoeken.vandale.nl. Woorden geraadpleegd op 17 apr. 2021.

Van Dale Groot woordenboek der Nederlandse taal, www.vandale.nl/klantenservice/meestgesteldevragen-van-dale-redactie\#ow_1. Opgevraagd 4 juli 2021.

Van der Geest, Michiel. "Pfizer levert binnen een maand half miljoen extra vaccins". De Volkskrant, 16 apr. 2021, www.volkskrant.nl/nieuws-achtergrond/pfizer-levert-binnen-een-maand-half-miljoenextra-vaccins $\sim$ b7955fa5. Opgevraagd 17 apr. 2021.

Van Gool, Rosa. "In Rome hoeven coronaregels niet logisch te zijn, als alles op papier maar klopt". De Volkskrant, 16 apr. 2021, www.volkskrant.nl/mensen/in-rome-hoeven-coronaregels-niet-logischte-zijn-als-alles-op-papier-maar-klopt bbc69978. Opgevraagd 17 apr. 2021.

Van Uffelen, Xander. "De belangrijkste grafieken en kaarten over de uitbraak van het coronavirus in Nederland". De Volkskrant, 16 apr. 2021, www.volkskrant.nl/nieuws-achtergrond/de-belangrijkstegrafieken-en-kaarten-over-de-uitbraak-van-het-coronavirus-in-nederland $\sim$ b18f4613. Opgevraagd 17 apr. 2021.

\section{NEOLOGISMEN IN CORONATIJD - EEN STEEKPROEF}

\section{S a m envatting}

In tijden van crisis wordt de taal vaak verrijkt met nieuwe woorden, de zogenoemde neologismen. Een uitzonderlijke situatie vraagt immers om nieuwe woorden. Dit geldt ook voor de coronacrisis. Zo krijgen de Nederlanders te maken met de anderhalvemetersamenleving en andere coronamaatregelen. Bovendien zorgt de crisis voor veel coronaschade, zowel economisch, psychisch als fysiek. Met de vaccinatiecampagne is de weg ingezet naar de terugkeer naar normaal. Ook deze route zorgt voor de nodige neologismen. In dit artikel wordt steeksproefgewijs gekeken welke neologismen zoal worden gebruikt op één bepaalde dag in één bepaalde krant. Aangezien de meeste neologismen bestaan uit samengestelde zelfstandige naamwoorden, zal de steekproef zich enkel hier op richten. Hiervoor wordt gebruik gemaakt van De Volkskrant online van 16 april 2021, en wel van de artikelen die verkregen werden na het invoeren van de zoekterm corona. Na een korte inleiding over neologismen en de verschillende soorten samenstellingen, worden de verkregen neologismen vervolgens gecategoriseerd volgens de verschillende categorieën samenstelling en volgens de coronathematiek. Tot slot wordt er op basis van de verkregen resultaten een conclusie getrokken.

Trefwoorden: coronacrisis; neologisme; samenstelling; media; steekproef; substantief. 


\title{
NEOLOGIZMY W CZASIE PANDEMII KORONAWIRUSA - PRÓBA BADAWCZA
}

\author{
Streszczenie
}

Wyjątkowa sytuacja wymaga nowych słów, stąd w czasach kryzysu język często wzbogaca się o neologizmy. Dotyczy to również kryzysu wywołanego koronowirusem. Niniejszy artykuł stanowi próbę użycia koronowirusowych neologizmów w języku holenderskim, danego dnia (16 kwietnia 2021 r.) w konkretnej gazecie (De Volkskrant online). Do badań wykorzystano artykuły wywołane hasłem „,corona”. Ponieważ większość neologizmów składa się z rzeczowników złożonych, próba skupia się na tychże właśnie. Po krótkim ogólnym wprowadzeniu na temat neologizmów i różnych typów złożeń, objęte badaniem jednostki są analizowane formalnie - według różnych kategorii złożeń i semantycznie - według tematyki związanej z koronawirusem.

Słowa kluczowe: kryzys wywołany koronawirusem; neologizm; złożenie; media; próba wyrywkowa; rzeczownik.

\section{NEOLOGISMS IN THE TIME OF THE CORONAVIRUS: A SELECTED SAMPLE}

\section{S u m m a ry}

In times of crisis language is often enriched with new words called neologisms. After all, extraordinary circumstances call for new words. This also applies to the corona crisis. For example, the Dutch have had to deal with the anderhalvemetersamenleving and other corona measures. Moreover, the crisis has caused a lot of "corona damage", both economically, psychologically and physically. The vaccination campaign has set the stage for a return to normality. This route also provides necessary neologisms. This article takes a look at which neologisms were used on one day in a particular newspaper. Since most neologisms consist of compound nouns, the sample will focus on these only. The De Volkskrant online edition, dated 16 April 2021, will be used for this purpose, using the articles obtained after entering the search term corona. After a short introduction to neologisms and the different types of compositions, the neologisms obtained are then categorised according to different composition categories and according to corona themes. Finally, a conclusion is drawn based on the results obtained.

Keywords: corona crisis; neologism; compound noun; media; sample; noun. 